\section{'Virus-proof' computer security system}

\section{Boston}

CAN computer operating be made safe from invading viruses, worms and determined hackers? Two computer scientists think the answer is "yes", and they have developed a computer security system which they claim is invulnerable to computer viruses such as the one that recently struck networks across the country (see Nature 336, 97 and 301; 10 and 24 November 1988).

The system, designed by Michael Rabin, a computer scientist at Harvard University, and his former student Douglas Tygar, now assistant professor in the School of Computer Science at CarnegieMellon University, is an adaptable set of programs designed to regulate access to information on computer systems.

The system, called ITOSS (Integrated Toolkit for Operating System Security), is the culmination of a four-year effort by Rabin and Tygar. Among its features is a battery of built-in 'sentinels' which can be employed either to warn away users from high-security data, or to record every access to sensitive data files without users' knowledge. A 'fingerprinting' algorithm can also alert system operators to any changes made to programs on the system. Included in the program's design are a 'minimum security' protection for all files against 'trojan horse' programs that might come into the system illicitly, hidden in innocuous messages, and a 'maximum security' feature which requires a specified number of system operators each to input commands in order to make any farreaching changes in the system.

New systems to protect computers are likely to be necessary if computer operators are to gain the upper hand over hackers. Last month, officials at Lawrence Livermore Laboratory gave up their battle with a hacker who had repeatedly infiltrated low-level security files on the laboratory's computer system. Instead, they left an invitation for the hacker to computer security manager. The hacker accepted the invitation and has now promised to stop his attacks. An FBI investigation is nevertheless under way.

Seth Shulman make direct contact with the laboratory's

\title{
Increase for West German ocean research
}

\section{Munich}

A sIzEABLE increase in support for ocean and polar research in West Germany was recommended last week by the influential Wissenschaftsrat, an independent science advisory board. The board recommended that an additional DM240 million should be spent over the next few years, with the money to come from both the federal and Länder governments.

The largest new investment recommended is for a DM75 million research centre in Hamburg which would bring together researchers from the University of Hamburg, the Max Planck Institute for Meteorology, the German Climate Computing Centre and the Federal Biological Research Establishment at Heligoland.

Research should be concentrated, the board says, on interactions between ocean and atmosphere as well as on the study of structure and function of marine ecosystems. The four institutions involved, which are funded out of as many different purses, would have to agree on how to carry out such an integration. Two new institutes are recommended for the Oldenburg/ Wilhelmshaven area, one to study the chemistry and biology of the ocean and the other to study coastal wetlands. Together they would cost DM40 million.

The Wissenschaftsrat also praised the Alfred Wegener Institute for Polar and Ocean Research in its first eight years as a Grossforschungseinrichtung (large research establishment). The leader of the Bremen institute, Gotthilf Hempel, wants to broaden its focus to include Arctic as well as Antarctic research and to include even more international cooperation. Hempel is chairman of the Arctic Ocean Sciences Board.

Steven Dickman

\section{$£ 520$ million plans for UK science park}

\section{London}

EVERY British university is trying to broaden its funding base and to forge links with industry. With that aim, a business park with a science centre at its core is planned for a 500-acre site near the University of Bristol. Details of the plans were released on 19 December.

The 5520 -million venture will include facilities for research, development and manufacturing, with space for 22 companies. These will have access to the 150 researchers based in the science centre who will come from the Universities of
Bristol and Bath and the Polytechnic of Bristol. Each institution has a 5 per cent stake, which is paid for in kind, with the provision of researchers and support staff.

A public inquiry must be held before the venture is approved because the site is on land released from environmental protection regulations. But Don Carleton, of the University of Bristol and director of the development company proposing the plans, says the planning authorities support the plans. He expects construction to begin next summer, and the park to create 14,000 new jobs.
Christine McGourty

\section{Tanks to hold more than fuel}

\section{Washington}

THE US space shuttle's giant external fuel tank will some day carry scientific experiments of its own, according to a memorandum of agreement signed last week between the National Aeronautics and Space Administration (NASA) and the Space Phoenix Program of the University Corporation for Atmospheric Research.

In his 1988 Commercial Space Initiative, President Ronald Reagan offered the external fuel tanks to anyone who could think of something interesting to do with them (see Nature 331, 550;1988). At present, the tanks are unceremoniously dumped into the ocean after providing the propellants to boost the shuttle into orbit.

There is an unpressurized, 5,000-cubicfoot space between the fuel and oxidizer tanks that can hold a pallet containing scientific instruments. According to Peter Riva, a spokesman for the Space Phoenix Program, that space can easily accommodate relatively large, low-technology experiments that can be loaded just before launch. Some experiments now being considered are gas releases into the upper atmosphere and detailed studies of the thermosphere.

Initial plans call for using the external tank during sub-orbital flights, but ultimately the Space Phoenix Program would like to find a way to place the tanks in more permanent, slow-decay orbits. There is no fixed timetable for when the external tanks will be used to carry experiments, but Riva expects the first flight will be sometime in 1991.

Joseph Palca

\section{Neuroscience Center} Boston

THE Harvard-affiliated Massachusetts General Hospital has opened a new \$18 million interdisciplinary Neuroscience Center. The centre, made up of 11 separate laboratories and with a staff of more than a hundred scientists, students, fellows and technicians, is financed by a $\$ 6.4$ million grant from E.R. Squibb and Sons, a $\$ 5$ million grant from the National Institutes of Health, and by a number of other private sources.

Dr Joseph Martin, professor of neurology at Harvard Medical School, will direct the new centre. Martin stresses the interdisciplinary approach of the centre, saying that chronic neurodegenerative diseases might best be tackled by "understanding their causes at the genetic level" rather than a "shotgun" approach of focusing only on particular symptoms of individual diseases. The centre will house the hospital's neurogenetics laboratory where molecular genetic techniques are being used to study Huntington's disease and Alzheimer's disease.
Seth Shulman 